\title{
VASS Zoltán
}

\section{Mit tehetünk és mit érhetünk el a fiatalok fizikai-lelki állapotának javítása érdekében?}

\begin{abstract}
A 2007-es tanulmányunk a testkultúra, a szabadidősport új kapcsolatait, jövőbeni kihívásait vizsgálta Magyarország jövőjével kapcsolatban, nem a biztos jót kívántuk bemutatni, hanem azokra a biztos és tudható rossz folyamatokra és azok hatásaira hívtuk fel a figyelmet, amelyek elkerülése minden józan ítélőképességgel bíró ember feladat. Tanulmányunkkal elsősorban arra kívántunk rámutatni, hogy a testkultúra mint a fizikai és kognitív funkciók leghatékonyabb fejlesztő eszköze, teljességgel kimaradt a kulcskompetenciák európai referenciakeretéböl. A paradoxon a következőképpen került megfogalmazásra: ha egy fenntartható társadalomnak aktív, innovatív, a tudásukat adaptívan alkalmazó polgárokra van szüksége, akkor kimaradhate az alapvető készségek referenciaköréből a testkultúra, különös tekintettel arra a tényre, hogy eme alapvető emberi készséget kizárólag az ontogenetikus fejlődés szenzitív szakaszaiban lehet a leghatékonyabban fejleszteni.
\end{abstract}

\section{Előzmények:}

A fent hivatkozott tanulmányban négy lehetséges forgatókönyvet vázoltunk fel arra vonatkozóan, melyek 2025-ig bekövetkezhetnek Magyarországon.

Az első alternatíva a technikai megújulás lehetőségeit vizsgálta, de a társadalmi gondolkodás megújulása nélkül, amelyben az egészségmegőrzés szintetikus táplálék-kiegészítőkkel történik és a prognózis szerint könnyen elképzelhetö, hogy 2025-re a felnövekvő fiatalok számára a testkultúra a társadalmi gondolkodás perifériájára szorul. Ez azt jelenti, hogy elmarad a társadalmi megújulás, és ezzel párhuzamosan a technikai megújulás veszi át a hétköznapi életvitelben megjelenö, az emberek gondolkodását irányító szerepet. Más szavakkal kifejezve tehát a rendszeres egészségvédő testmozgást felváltja a szintetikus táplálék-kiegészítők alkalmazása az egészség fenntartása érdekében.

A második alternatíva az első alternatívához hasonlóan a technikai megújulás lehetőségeit vizsgálta társadalmi megújulás nélkül, amelyben a generációk számára az egészség olyan luxuscikk lesz, amelynek „beszerzése” rengeteg pénzt és energiát követel meg. Ennek alapján elképzelhető, hogy a magyar társadalom igen rövid idő alatt eljuthat egy eddig elképzelhetetlennek tűnő, majdhogynem utópisztikus állapotba, amelyben az egészség valóban olyan luxuscikknek fogható fel, mint mondjuk egy jacht megvásárlása manapság.

A harmadik alternatíva a legkívánatosabb forgatókönyvet vázolta fel, amiben a társadalmi megújulás és a technikai megújulás együtt következik be, és amelyben a közoktatásban létrejövő reformok hatására a testnevelés hatékonyan hozzájárul a kulcskompetenciák fejlesztéséhez és megjelenik egy új „egészségtudatos, jövőorientált" kulcskompetencia. Ennek megfelelően a köz- és felsőoktatásban résztvevő fiatalok képzésébe még intenzívebb, magasabb hatásfokkal müködö oktatási rendszert kerül bevezetésre. A jövő iskolájában a testkultúrát népszerüsítő tárgyak, mint például a mai testnevelés, megújulnak, a tananyag pedig a kor társadalmi igényei szerint alakul át. Ez azt jelenti, hogy a sportmozgás - és 
egyáltalán a mozgás - nemcsak célja, hanem nagyon fontos eszköze lesz a kognitív funkciók fejlesztésének. E megújulási folyamatok hátasára a testnevelés hatékonyan kapcsolódik majd egyes közismereti tárgyak oktatásához, de általánosságban hatékony kreativitás- és gondolkodásfejlesztő eszközként fog megnyilvánulni. A mindennapos testnevelés nemcsak a tanulók fizikai képességeinek hiányát kompenzálja majd, hanem a kognitív szféra célirányos fejlesztése is teret kap benne.

A negyedik alternatíva a társadalmi megújulás a technikai megújulás mellett a felsőoktatásban, a testnevelő tanárképzésben megjelenő innovatív, kreatív szakemberek képzésének témakörét járta körbe, hiszen magas színvonalú kognitív fejlesztés a közoktatásban a mozgáson keresztül csakis magasan képzett, az új felfogásnak megfelelő és ezek szerint gondolkodó pedagógusokkal lehetséges.

A továbbiakban kiválasztottuk a "Társadalmi megújulás a technikai megújulás mellett, amelyben a közoktatásban létrejövő reformok hatására a testnevelés bekerül a kulcskompetenciák körébe" című forgatókönyvet, melynek kapcsán részletesen bemutatjuk a 2007 óta bekövetkező változásokat és felvázoljuk, hogy mit tehetünk és mit érhetünk el a fiatalok fizikai-lelki állapotának javítása érdekében.

\section{Milyen tendenciák figyelhetök meg 2007-töl napjainkig?}

Sajnálatos módon kijelenthető, hogy 2007 óta a mozgásszegény életvezetési szokások növekvő térhódítása minden korosztálynál jelentős mértékű, ezért megkerülhetetlen kérdéssé vált napjainkban, a világban, így Európában is, hogy az életpályán átívelő stratégiák ne csupán az anyagi életfeltételek megteremtését támogassák, hanem az életminőséget befolyásoló, a testi és lelki egészség kialakításához kapcsolódó készségek és kompetenciák fejlesztését is.

Mint azt jól tudjuk, az egészségtudatos, jövőorientált életvezetés komplex tevékenységek összefüggő rendszerét jelenti. A tevékenységek középpontjában kiemelt jelentőséggel bír a fizikailag aktív életmód kialakítása, fenntartása, ami az egészséges fizikai és lelki állapot megőrzésében, az optimális testsúly és energia-egyensúly fenntartásában, valamint a kedvező kockázati magatartásban követhető nyomon. ${ }^{1}$ Mindezek ellenére a 2009-es kutatási eredmények azt mutatják, hogy a magyar lakosság 77\%-ára nem jellemző a fizikailag aktív életmód, ezen belül a lakosság 59\%-a egyáltalán nem végez semmilyen fizikai aktivitást. ${ }^{2} \mathrm{~A}$ 2014-es eurobarométer adatok alapján javulás mutatható ki a magyar lakosság fizikai aktivitási szokásainak tekintetében, de még így is messze elmarad a fejlett gazdasági országok mögött. ${ }^{3} \mathrm{~A}$ képet tovább árnyalja, hogy csupán a megkérdezettek $8 \%$-a végez rendszeres testmozgást kifejezetten az optimális testsúly kialakítása érdekében, ami - figyelembe véve a magyar lakosság testsúlyproblémáit - különösen elgondolkodtató. A fenti adatok tükrében egyáltalán nem meglepő, hogy a felnőtt magyar lakosságon belül a túlsúlyosok aránya az elmúlt 20 évben, hasonlóan az európai trendekhez - életkortól függetlenül - a férfiaknál kétszeresére, a nőknél másfélszeresére emelkedett. ${ }^{4}$ A kutatási adatok elemzése alapján

\footnotetext{
${ }^{1}$ Kockázati magatartásnak nevezik az alkohol, cigaretta, drog használatát és egyéb egészséget befolyásoló tényezőket

${ }^{2}$ Special Eurobarometer [2010]: Sport and Phisical Activity. Forrás: http://ec.europa.eu/public_opinion/archives/ebs/ebs_334_fact_hu_en.pdf

${ }^{3}$ Special Eurobarometer 412 [2014] Sport and physical activity, Report. Forrás:http://ec.europa.eu/public_opinion/archives/ebs/ebs_412_en.pdf

${ }^{4}$ Országos Táplálkozás és Tápláltsági Állapot Vizsgálat - OTÁP2009. Forrás: http://www.oeti.hu/?m1id=16\&m2id=169
} 
összességében megállapítható, hogy a magyar felnőtt lakosság életvezetési és gondolkodási szokásaira a fizikai aktivitás, és a jövőorientált gondolkodás kevésbé jellemző, melynek bizonyítéka a népegészségügyi mutatók kedvezőtlen alakulásában is kimutatható.

A magyar felnőtt lakosságnál megfigyelhető negatív tendenciák a 2007-2015-ös időszakra vonatkozóan sajnálatos módon a magyar fiatalok körében is tetten érhető. A Magyar Ifjúság 2012 kutatás tanulmányából kiderül, hogy bár a 15-29 év közötti fiatalok közel azonos mértékű szabadidővel rendelkeznek, ennek ellenére az életkor előrehaladtával egyre kevesebben sportolnak, és mindössze 16-18\%-uk választja szabadidejében a sporttevékenységeket. A magyar ifjúság 70\%-a szabadidejét otthon tölti, s közel 60\%-a internetezik, számítógépezik, vagyis passzív, fizikailag inaktív, ülő életmódot folytat. A fenti adatok tükrében látható, hogy a technológia-gazdag társadalomra jellemzően a mai fiatalok élete sokkal inkább a jelen- és élményorientált tevékenységek köré szerveződik, amivel a következetes, rendszeres munkát és kitartást igénylő fizikai aktivitások és sporttevékenységek nehezen tudnak versenyezni. ${ }^{5} \mathrm{Az}$ egészségmagatartással kapcsolatos jelenorientált viselkedés egyik oka lehet, hogy az alacsony fizikai aktivitási szint ellenére ebben az életszakaszban még nem jellemzők az életminőséget befolyásoló, nem fertőző, krónikus megbetegedések. Éppen ezért kiemelten fontos teendő a hazai köznevelésben részt vevő gyermekek és tanulók számára megmutatni azokat a lehetőségeket, átadni azokat az ismereteket és készségeket, valamint kialakítani azokat az attitűdöket, amelyek megalapozhatják a felnőttkori egészségtudatos, jövőorientált életvezetést.

\section{Mit tehetünk a fiatalok fizikai-lelki állapotának javítása érdekében 2025-ig (félelmek)?}

$A z$ iskolai testnevelés területét érintő európai uniós szakpolitikák közös jellemzője az, hogy azok szubszidiárius, azaz kiegészítő jellegúek, ahol az elsődleges hatáskör a tagállamoknál található. Azonban Magyarország az uniós szakpolitikai ajánlások mentén - azokat tagállami szinten támogatva - képes kezdeményezőként fellépni a minőségi testnevelést is támogató egészségvédő testmozgás népszerűsítése, fejlesztése érdekében, elsősorban az oktatás területén.

A 2020-ig terjedő időszakban a célkitűzések szerint az európai oktatási és képzési együttmúködést az egész életen át tartó tanulás elvére építő, koherens stratégiai keretrendszerben szükséges kialakítani, mely valamennyi - a formális, a nem formális és az informális - tanulási színtérre és az oktatás, képzés valamennyi szintjére kiterjed. Az egész életen át tartó tanulásra építő keretrendszert az Európai Parlament és a Tanács egész életen

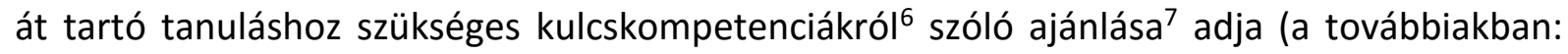
kulcskompetenciák referenciakerete), a tanulás (oktatás és képzés) szintjeire vonatkozó - a

\footnotetext{
${ }^{5}$ Bauer Béla, Szabó Andrea (szerk.) : Arctalan (?) nemzedék : ifjúság 2000-2010. Budapest, 2011, Nemzeti Család-es Szociálpolitikai Intézet, ISBN 978-963-7366-38-3. Forrás: ncsszi.hu/download.php?file_id=1403

${ }^{6}$ A kulcskompetenciák azok a kompetenciák, amelyekre minden egyénnek szüksége van a személyes önmegvalósításhoz és fejlődéshez, az aktív polgársághoz, a társadalmi beilleszkedéshez és a foglalkoztatáshoz.

${ }^{7}$ Az Európai Parlament és a Tanács ajánlása (2006. december 18.) az egész életen át tartó tanuláshoz szükséges kulcskompetenciákról (2006/962/EK). Forrás: http://eur-

lex.europa.eu/LexUriServ/LexUriServ.do?uri=CELEX:32006H0962:HU:NOT
} 
referenciakerethez szorosan kötődő - uniós keretrendszert pedig az egész életen át tartó tanulás Európai Képesítési Keretrendszere (a továbbiakban: EKKR) ${ }^{8}$ jelenti.

Mint arra már a 2007-es tanulmányunkban rámutattunk a kulcskompetenciák 2006-ban elfogadott európai uniós referenciakeretét elemezve elmondható, hogy ugyan a szociális és állampolgári kulcskompetencia-terület leírásában - általánosságban - még tetten érhető az elvárt és keresett egészségfejlesztési tartalom, ${ }^{9}$ azonban az egészségtudatos, jövőorientált életvezetéssel összefüggő ismeretek, készségek, attitűdök hálózata már egyáltalán nem jelenik meg abban, mely komoly hátrányt jelent az iskolai testnevelés fejlesztése tekintetében is.

Szintén komoly kihívást jelent az egyes kulcskompetenciák mérésére alkalmas mérőeszközök kifejlesztése is. Míg az anyanyelven és az idegen nyelveken folytatott kommunikáció, a matematikai kompetencia, az alapvető kompetenciák a természet- és múszaki tudományok terén a legtöbb tagállam rendelkezik mérési és nyomon követési eszközökkel a kötelező oktatásban (és alkalmazza is azokat), addig - többek között - a szociális és állampolgári kompetenciák tekintetében elvétve, vagy egyáltalán nem.

A referenciakeret e hiányosságai miatt - természetszerúen - az EKKR-ben meghatározott tanulási eredmények (tudás, készségek, kompetencia) sem képesek érdemben kapcsolódni az egészséges életvezetéshez mint a szociális és állampolgári kulcskompetencia körében meghatározott portfólió-elemhez.

A gyakorlati megvalósítás szintjén ez azt jelenti, hogy már rövidtávon nagyobb hangsúlyt kell helyezni az egészségfejlesztést előtérbe helyező és interszektorális megközelítésű egészségpolitikára mind közösségi, mind tagállami szinten, kifejezetten és célzottan az egész életen át tartó tanulás politikájában. E téren hazánk a köznevelési törvénnyel és ez ehhez kapcsolódó köznevelés-szabályzó eszközökkel példát mutat az ágazatokon átívelő együttmúködésre.

Ezzel összefüggésben megfelelő erőforrásokat kell rendelkezésre bocsájtani az egészségvédő testmozgás (health-enhancing physical activity, a továbbiakban: HEPA) ágazatközi előmozdítására is. $A z$ egészségvédő testmozgás koncepciójának európai uniós fejlődéstörténete eklatáns példát szolgáltat ahhoz, hogy belássuk: mivel az Európai Unió joganyaga és az acquis communataire folyamatos változásokat mutat, ezért permanens fejlesztésre is szorul. A sport 2007-ben - a gyakorlatban azonban csak 2009. december 1. napján, a lisszaboni szerződés hatályba lépésével ${ }^{10}$ - vált szubszidiárius európai uniós hatáskörré, jóval azt követően, hogy az Európai Parlament és az Európai Unió Tanácsa elkészítette ajánlásait a kulcskompetenciák referenciakeretéről és az EKKR létrehozásáról.

\footnotetext{
${ }^{8}$ Az Európai Parlament és a Tanács ajánlása (2008. április 23.) az egész életen át tartó tanulás Európai Képesítési Keretrendszerének létrehozásáról. [Hivatalos Lap C 111., 2008.5.6.]. Forrás: http://eurlex.europa.eu/legal-content/HU/ALL/?uri=CELEX:32008H0506(01)

9 „A szociális kompetencia kapcsolódik az egyéni és társadalmi jól-léthez, és megköveteli annak megértését, ahogyan az egyén saját ideális fizikai és mentális egészségét biztosítani tudja, ideértve ennek a maga és családja, illetve közvetlen társadalmi környezete számára szolgáló forrásként való felismerését, valamint annak ismeretét, ahogyan az egészséges életvitel mindehhez hozzá tud járulni."

${ }^{10}$ Lisszaboni Szerződés, XII. CÍM, OKTATÁS, SZAKKÉPZÉS, IFJÚSÁG ÉS SPORT. Forrás: http://europa.eu/lisbon_treaty/full_text/index_hu.htm
} 
Ebből fakadóan az európai sport szakpolitika - így a HEPA koncepció - jelenlegi alakítói akkor még képtelenek voltak befolyásolni az egész életen át tartó tanulás rendszerét.

Figyelembe véve ugyanakkor a korábbiakban hivatkozott hosszú távú várakozásokat és középtávú célkitǔzéseket, időszerűnek látszik, hogy a kulcskompetenciák referenciakeretét az EU érintett intézményei felülvizsgálják, a tagállamok pedig - így különösen Magyarország kezdeményezői legyenek ennek a szupervíziós folyamatnak.

Ebből a szempontból az egészségvédő testmozgás napjainkban kibontakozó koncepciójának megvalósítása ideális érvként hozható fel a változtatás szükségességének alátámasztásakor, hiszen a HEPA abban a tekintetben mindenképpen egyedülálló szakterület az Európai Unióban, hogy dedikáltan ágazatközi, interszektorális. Ahogy a sport európai dimenziójának fejlesztéséről szóló közlemény ${ }^{11}$ fogalmaz: „a tagállamok között nagy különbségek tapasztalhatók a fizikai aktivitási szintek és megközelitések szempontjából, és jelentős kihivásokat támaszt az egészségvédő testmozgás koncepciója, amely olyan változatos ágazatokat fog át, mint a sport, az egészségügy, az oktatás, a közlekedés, a várostervezés, a közvédelem és a munkakörnyezet."

Ahhoz tehát, hogy az EU oktatási szakpolitikáját érintő változtatásokat lehessen - akár tagállami kezdeményezésre - középtávon eszközölni, érdemes lehet a fenti szellemben megkomponált tagállami HEPA rendszereket, jó gyakorlatokat felépíteni.

Erre vonatkozóan szintén létezik felhatalmazó iránymutatás, hiszen az egészségvédő testmozgás ágazatközi előmozdításáról szóló 2013-as ajánlásban ${ }^{12}$ az Európai Unió Tanácsa kifejezetten felhívja a tagállamokat, hogy "többek között a sport, az egészségügy, az oktatás, a környezetvédelem és a közlekedés szakterületére kiterjedö ágazatközi megközelítést kialakítva, az Unió testmozgásra vonatkozó iránymutatásainak és egyéb érintett ágazatoknak a figyelembevételével, továbbá a nemzeti sajátosságoknak megfelelöen dolgozzanak ki az egészségvédő testmozgást népszerüsitő hatékony szakpolitikákat."

\section{Mit tehetünk a fiatalok fizikai-lelki állapotának javítása érdekében 2025-ig (remények)?}

Az elmúlt években született oktatásirányítási döntések - így elsősorban a nemzeti köznevelésről szóló 2011. évi CXC törvény (a továbbiakban: köznevelési törvény) egésze, valamint a mindennapos testnevelést előíró része, az alapvető tartalmi szabályozók: az új Nemzeti alaptanterv, a hozzá tartozó kerettantervek bevezetése, valamint a nevelési-oktatási intézmények müködéséről és a köznevelési intézmények névhasználatáról szóló 20/2012. (VIII. 31.) EMMI rendelet (a továbbiakban: 20/2012. (VIII. 31.) EMMI rendelet) teljes körü egészségfejlesztésre vonatkozó előírása - ugyanakkor már jelentős szemléletbeli változást vetítenek előre a testi és lelki egészség kialakításához kapcsolódó készségek és kompetenciák kialakítását illetően.

\footnotetext{
${ }^{11}$ A BIZOTTSÁG KÖZLEMÉNYE AZ EURÓPAI PARLAMENTNEK, A TANÁCSNAK, AZ EURÓPAI GAZDASÁGI ÉS SZOCIÁLIS BIZOTTSÁGNAK ÉS A RÉGIÓK BIZOTTSÁGÁNAK, A sport európai dimenziójának fejlesztése. Forrás: http://eurlex.europa.eu/LexUriServ/LexUriServ.do?uri=COM:2011:0012:FIN:HU:PDF

${ }^{12}$ A TANÁCS AJÁNLÁSA (2013. november 26.) az egészségvédő testmozgás ágazatközi előmozdításáról (2013/C 354/01) Forrás: http://eurlex.europa.eu/LexUriServ/LexUriServ.do?uri=OJ:C:2013:354:0001:0005:HU:PDF
} 
Az egészségvédő testmozgást népszerűsítő hatékony szakpolitika illetve a minőségi testnevelés megvalósítása érdekében a Kormány felkérte a Magyar Diáksport Szövetséget, tárja fel és mutassa be a testnevelés jelenlegi hazai helyzetét, tegyen javaslatot a következő hétéves periódus oktatást és képzést érintő jogalkotási feladataira, valamint a szakmódszertani, az emberi erőforrás, eszköz-, illetve az infrastruktúrát érintő fejlesztésekre. A T.E.S.I. 2020 névre keresztelt stratégiát a Magyar Diáksport Szövetség a hazai köznevelés és az Európai Unió 2020-ig szóló intelligens, fenntartható és inkluzív növekedést biztosítani kívánó stratégiájával, valamint magyar gazdaság teljesítőképességével összhangban dolgozta ki.

A jelzett szemléletváltásból fakadóan 2013 és 2014 fordulóján halaszthatatlan feladatként jelentkezett a minőségi testnevelés stratégiai alapokon nyugvó fejlesztési útvonaltervének az oktatás és képzés teljes vertikumára kiterjedő - meghatározása, annak részeként pedig a korszerű, minőségi testnevelés alapelveinek és fő fejlesztési területeinek rendszerszintű kidolgozása.

A minőségi testnevelés célja olyan módszertani, tartalmi keret és hatásrendszer biztosítása, melynek eredményeként - a köznevelési szakasz végére - a tanulókban kialakul az egészségtudatos, jövőorientált életvezetési kompetencia. A minőségi testnevelés ennek megfelelően a jövőorientált egészségtudatos életvezetési kompetenciát kialakítani - de legalábbis ahhoz hozzájárulni - képes, mérhető, ezáltal tervezhető és ellenőrizhető szakpedagógiai hatásrendszer.

A Magyar Diáksport Szövetség a TÁMOP-3.1.13-12-2013-0001 azonosító számú, kiemelt projektjében a fenti bekezdésben leírtaknak megfelelően kidolgozta a minőségi testnevelés oktatási keretrendszerét. A projekt célja olyan módszertani, és tartalmi keret biztosítása volt, amely megteremti az alapot a múveltségterületi oktatásban országosan egységesen alkalmazható oktatásmódszertani gyakorlathoz, valamint egymáshoz közelíti testnevelésórai fejlesztési hangsúlyokat. A fejlesztő munka eredményként előálló minőségi testnevelés oktatási keretrendszerének elsődleges célja, hogy a tanítási folyamatban - a kompetenciaszemléletnek és az oktatási keretrendszerben megjelenő alapelveknek megfelelően - hangsúlyos szerepet kapjon a tanulók mozgásműveltségének fejlesztése mellett az egészség- és személyiségfejlesztés. A fentiek értelmében az oktatás során tehát nem a szervezet funkcionális jellemzőinek fejlesztése, edzése, illetve a fittségi állapot javítása az egyedüli feladat, hanem hangsúlyosan meg kell jelennie a konstruktív ön- és közösségfejlesztő tanulói magatartás formálásának és a tevékenységrepertoár bővítésének.

Az alábbi ábrán bemutatjuk a minőségi testnevelés oktatási keretrendszerének kapcsolódását a köznevelés tartalmait meghatározó dokumentumokhoz, a NAT 2012 és annak kerettanterveihez, az MKKR 1-4. szintjeihez, és az LLL-kulcskompetenciákhoz (1. ábra). 


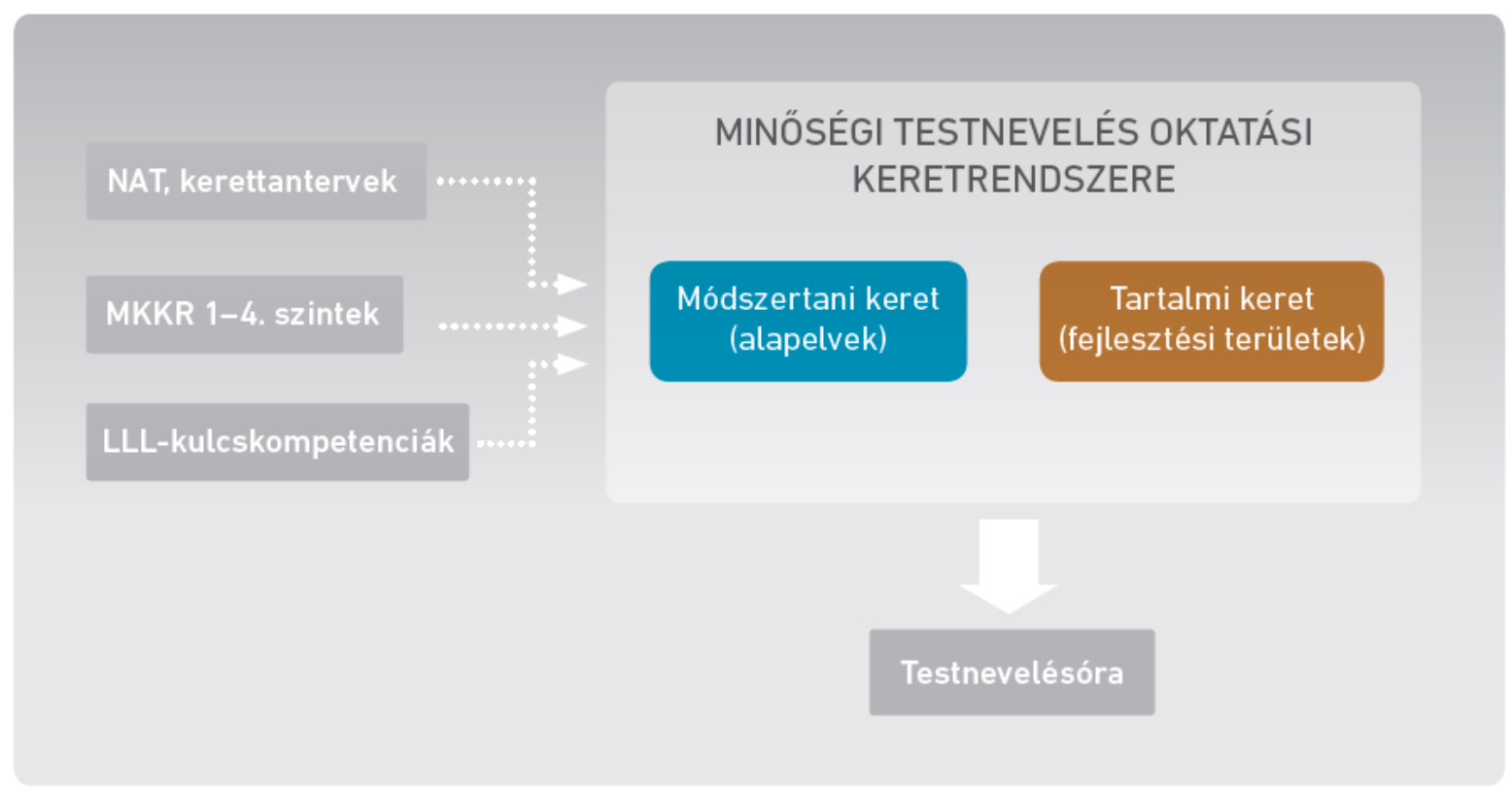

1. ábra: A minöségi testnevelés oktatási keretrendszere és a testnevelés oktatását meghatározó dokumentumok kapcsolata

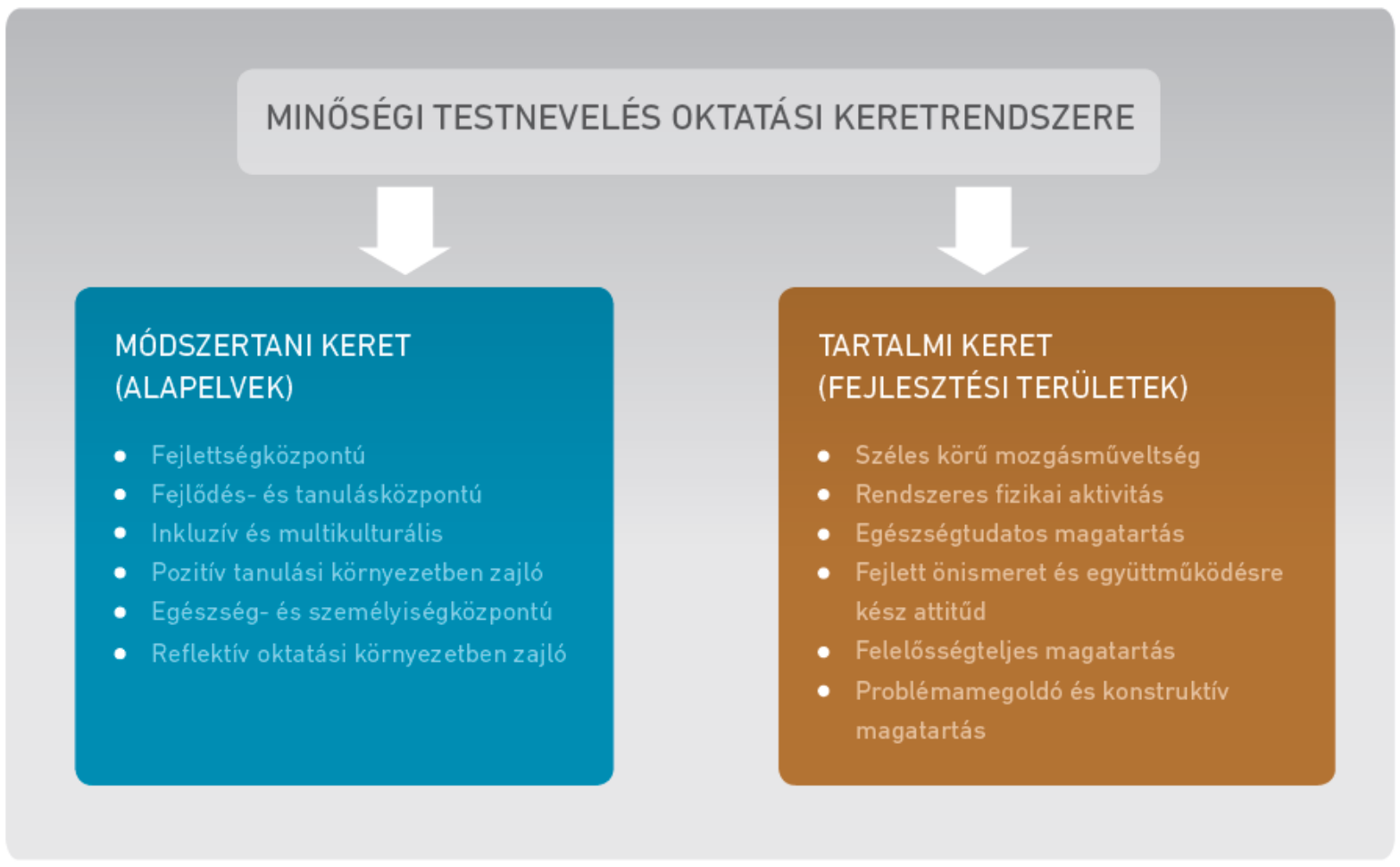

2. ábra: A minőségi testnevelés oktatási keretrendszere

A minőségi testnevelés oktatási keretrendszerében található fejlesztési területek meghatározása során kiemelt törekvés volt, hogy a teljes fizikai, szellemi és szociális jóllét állapotának elérését biztosító elemek a fejlesztési területekbe integráltan, illeszkedve a teljes körű iskolai egészségfejlesztés témaköreihez, a műveltségi területre jellemzően jelenjenek meg. 
Ennek megfelelően az első három fejlesztési területen (széles körű mozgásműveltség, rendszeres fizikai aktivitás, egészségtudatos magatartás) alapvetően a NAT 2012-ben és a ráépülő kerettantervekben megjelenő tartalmak kerültek döntően megjelenítésre a fizikai jóllét állapotának teljes körű fejlesztése érdekében. Továbbá itt kerültek integrálásra a teljes körú iskolai egészségfejlesztésben megjelenő alábbi tartalmak, mint például:

- a testmozgás és az egészség, betegség kapcsolata,

- az egészséghez szükséges testmozgás,

- a szervezet fejlődése testmozgással és annak hiányában,

- a felnőtt szervezet múködése testmozgással és annak hiányában,

- gerincvédelem, gerinckímélet,

- a krónikus, nem fertőző megbetegedések megelőzése.

A negyedik, ötödik és hatodik fejlesztési terület (fejlett önismeret és együttmüködésre kész attitűd, felelősségteljes magatartás, problémamegoldó és konstruktív gondolkodás) alapvetően a testnevelés-órai mozgásos tartalmakon keresztül történő szellemi és szociális jóllét fejlesztésének érdekében került kialakításra. Továbbá itt kerültek integrálásra a teljes körű iskolai egészségfejlesztésben megjelenő alábbi tartalmak, mint például:

- önismeret, önértékelés, a másikat tiszteletben tartó kommunikáció módjai, szerepe a másik önértékelésének segítésében,

- társas kapcsolatok,

- az érett, autonóm személyiség jellemzői.

\section{Mi várható 2050-ig? (prognózis, záró gondolatok)}

\section{Idösödő Európa}

A népesség öregedési trendjét legszemléletesebben a korfák mutatják. Az EU tagállamaiban általános jelenség, hogy a korfa alja elkeskenyedik: ez a termékenység csökkenésének a hatása. Ezzel párhuzamosan a korfa teteje egyre jobban kiszélesedik, hiszen nő a születéskor várható élettartam. A demográfiai előrejelzések alapján az EU korfája 2050-re egy csúcsára állított piramisra fog emlékeztetni, azaz kevés lesz a fiatal, és sok az idős. Magyarország 2000. évi és 2050-re várható korfájának elkeskenyedését mutatja az OECD-től kölcsönzött alábbi ábra.

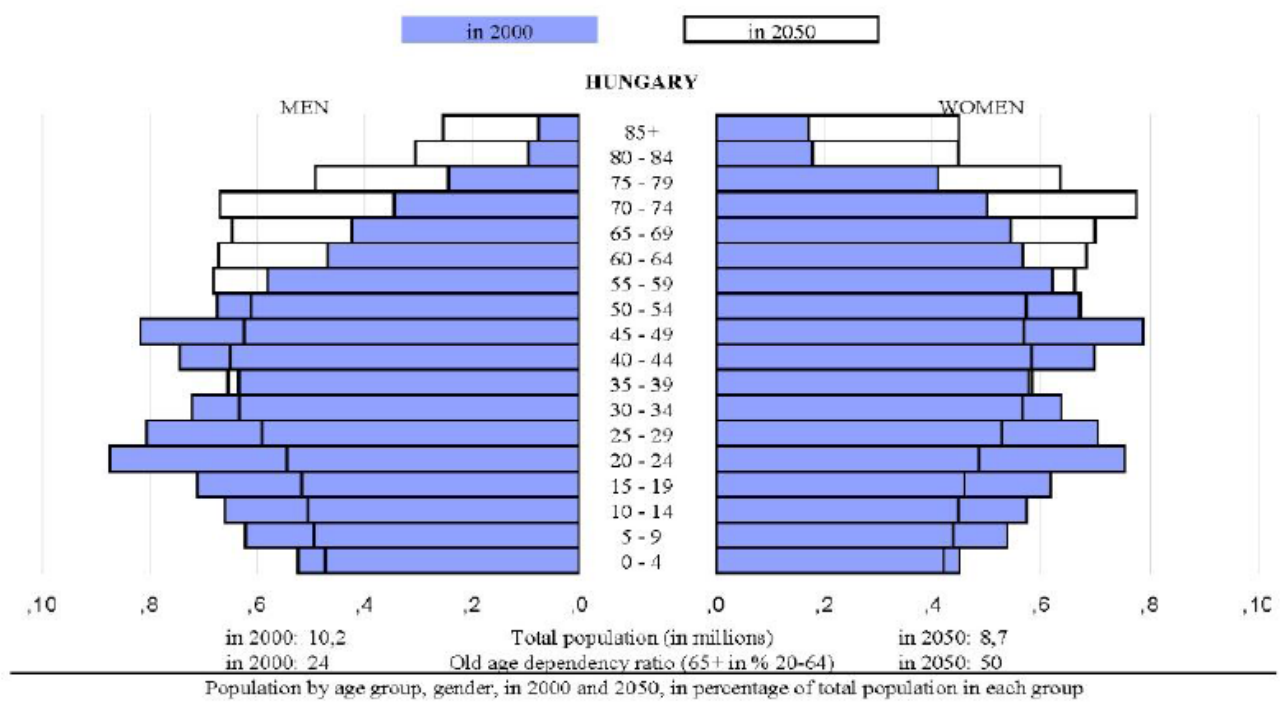


Jelen tanulmányban felvázolt szakpolitikai hiányosságoknak és a megváltozott életvezetési szokásoknak különösen annak fényében van relevanciája, hogy tekintettel az idősödő európai társadalmakra, az Európai Unió tagállamaiban mindkét nem tekintetében egyre magasabb életkorban meghatározott nyugdíjkorhatárokkal találkozhatunk, ráadásul ez a tendencia egyértelmúen folytatódni látszik az Európai Bizottságnak a megfelelő, biztonságos és fenntartható európai nyugdíjak menetrendjéről szóló fehér könyve alapján. ${ }^{13}$

A munkaképes korú népesség lélekszáma az előrejelzések szerint 2010-ig nő, utána viszont csökkenni fog, az EU országaiban 2004 és 2050 között átlagosan 16\%-kal. Az új tagállamokban a $16 \%$-os átlagnál nagyobb (27\%) lesz a csökkenés. Magyarországon az aktív korúak száma 2050-re 25\%-kal lesz alacsonyabb. A 65 év felettiek számában drasztikus emelkedés várható 2050-ig: az EU új tagállamaiban ez a korosztály 88\%-kal, a régi tagállamokban 75\%-kal lesz népesebb, mint 2004-ben.

A legnagyobb növekedés a 80 év fölöttiek esetében várható: az ő arányuk az EU tagállamainak átlagában 174\%-kal lesz nagyobb a jelenleginél. Pillanatnyilag minden ötödik magyar állampolgár betöltötte a 60. életévét, mégsem tartozunk Európában a legöregebb kormegoszlású országok közé. A 60 éven felüliek arányának növekedése 2008 és 2030 között felgyorsul, és 2050-ben az össznépességhez viszonyítva eléri a 35\%-ot, miközben a 65 éven felüliek aránya a 2001. évihez viszonyítva majdnem a duplájára nő. Míg a 60-69 éves korcsoport aránya csökkenő tendenciát mutat 2050-ig és a 70-79 éveseknél kismértékű növekedés várható, a 80 éven felüliek arányának növekedése valóban drasztikus lesz. ${ }^{14}$

Ha figyelembe vesszük ezt a körülményt, akkor ki kell jelentenünk: az Európai Uniónak a gazdasági növekedéshez közép- és hosszú távon olyan állampolgárokra lesz szüksége, akik legalább 70 éves életkorig munkaképességük birtokában vannak, így jelen tudnak lenni - és jelen is lesznek - a munkaerőpiacon. Ehhez képest jól szemlélteti a jóléti társadalmak helyzetét, hogy Magyarországon a születéskor várható élettartam a férfiak esetében 72,01 év, nők esetében 78,73 év (átlagosan 75,3 év). Az EU 28-ak átlagában ez a szám a 2011-es mutatók alapján átlagosan 80,3 év ${ }^{15}$. Az egészséges életvitelhez szükséges készségek, ismeretek és attitűdök elsajátítása a fenti mutatókat figyelembe véve tehát egyidejűleg foglalkoztatási és életminőségi kérdéssé is vált. ${ }^{16}$

Ehhez kapcsolódóan érdemes megemlíteni azt a tényt is, hogy míg az Európai Unióban folyamatosan nő az egészségesen várható élettartam, addig Magyarországon még mindig jelentősen elmarad az európai uniós átlagtól a magyarok egészségben eltöltött éveinek száma. A legfrissebb, 2013. évi adatok szerint az európai térség államaiban a születéskor várható egészséges életévek száma a férfiak esetében Izlandon (71,7 év), nők esetében Máltán (72,2 év) a legmagasabb. Ezek a mutatók Lettországban a legalacsonyabbak mindkét nem esetében (férfiak: 51,7 év, nők: 54,2 év). Magyarországon ez az érték a férfiak esetében 59,1 év (EU átlag: 61,4 év), míg a nők körében 60,1 év (EU átlag: 61,5). A legmagasabb és a legalacsonyabb élettartam közötti különbség (a rangsor első és utolsó helyezettje közötti eltérés)

\footnotetext{
${ }^{13}$ Európai Bizottság, Fehér könyv, A megfelelő, biztonságos és fenntartható európai nyugdíjak menetrendje, COM(2012) 55 final, Brüsszel, 2012.2.16. Forrás:http://ec.europa.eu/social/BlobServlet?docld=7341\&langld=hu

${ }^{14}$ Farkas Gabriella, Gyarmati Andrea, Molnár Szilárd: Az idősödő társadalom gazdasági és társadalmi kihívásai Magyarországon

${ }^{15}$ Központi Statisztikai Hivatal, Forrás: https://www.ksh.hu/docs/hun/xstadat/xstadat_eves/i_wdsd008.html, valamint http://www.ksh.hu/docs/hun/xstadat/xstadat_eves/i_int008.html

${ }^{16}$ A témában lásd: A Tanács következtetései - Az egészségben való megöregedés mint az egész életcikluson át tartó folyamat (2012/C 396/02). Forrás: http://eur-lex.europa.eu/LexUriServ/LexUriServ.do?uri=OJ:C:2012:396:0008:0011:HU:PDF
} 
elképesztően magas: a nőknél 18, a férfiak körében 20 év. Magyarország a mezőny hátsó harmadában, a huszadik helyen található a 28 európai uniós ország rangsorában. ${ }^{17}$

A megfelelő, biztonságos és fenntartható európai nyugdíjak Európai Bizottság által felvázolt a korábbiakban már hivatkozott - menetrendje azt vetíti előre, hogy a születéskor várható élettartam további emelkedése, ezzel összefüggésben pedig a 60 éven felüliek számának dinamikus növekedése és az aktív munkaképes korúak (20-59 éves) számának csökkenése a következő évtizedekben csökkenti a gazdasági növekedés lehetőségét. Mindez a gyakorlatban azt jelenti, hogy 2060-ra a nyugdíjak az állami kiadások egyre nagyobb részét, átlagosan a GDP több mint 10 \%-át teszik majd ki, amely bizonyosan rendkívüli nyomást gyakorol majd az államháztartásokra. Az Európai Bizottság szerint az öregedő Európában a nyugdíjkorhatár emelése segíthet fenntartani - sőt akár növelni - a bérpótlási arányok (a korábbi keresethez viszonyított nyugdíj) későbbi szintjét. Ennek eszközeként a tagállamoknak néhány évtizedes távlatban meg kell valósítaniuk a nyugdíjkorhatárok összekötését a várható élettartam növekedésével, a korkedvezményes nyugdíjrendszerekhez való hozzáférés és a munkaerőpiacról való más korai kilépési lehetőségek korlátozását, vagy éppen a nők és férfiak nyugdíjkorhatárának egyenlővé tételét. Ennek megfelelően tehát az uniós tagállamoknak is fel kell készülniük arra, hogy a jelenlegi gyermek- és fiatalkorú, valamint fiatal felnőtt korosztálynak még tovább kell a munkaerő-piacon maradnia, mint a jelenleg aktív munkavállalóknak. Az Európai Bizottság ehhez igazodóan eszközként definiálja azt is, hogy az egész életen át tartó tanuláshoz való könnyebb hozzáférés révén - meg kell hosszabbítani a munkában eltöltött időt, és - az aktív és egészséges időskor támogatása révén - az idősebb munkavállalók számára foglalkoztatási lehetőségeket kell biztosítani.

A már bemutatott demográfiai és munkaerőpiaci tendenciák miatt egyértelműen a relatív egészséget, a jól-létet és a függetlenséget minél hosszabb ideig biztosítani képes, új szemléletű idősödési modellekben kell gondolkodnunk. Fontos szem előtt tartani, hogy az idősödésre és az időskorra nem lehet egységes, egysíkú életszakaszként tekinteni, valamint azt is, hogy nem a „naptári évek" szerint idősödünk, hiszen az idősödés folyamata szoros összefüggésben áll az egyén egész életútjával (Iván 2002) ${ }^{18}$.

Az Európai Unió tagállamai közül Magyarországon és Észtországban számíthatnak legkevésbé arra az emberek, hogy ötvenéves koruk után még hosszú ideig élnek majd egészségesen. Míg például egy dán férfi az ötvenedik életéve betöltésekor átlagosan további 28,3 év megélésére számíthat, s ebből várhatóan közel 24-et egészségesen tölthet el, addig egy ugyanilyen idős magyar társa az átlagosan hátralévő 23 évéből csak 10,8-at él meg tartós betegség nélkül, vagyis nagy eséllyel már a most érvényes nyugdíjkorhatár, a 62. év elérése előtt állandó betegséggel fog küzdeni.

\footnotetext{
${ }^{17}$ Eurostat 2013.

${ }^{18}$ Iván László (2002): Az öregedés aktuális kérdései. Magyar Tudomány, 2002/4 412. o.
} 